\title{
Listeria monocytogenes in ham sliced in supermarkets in Recife city, Pernambuco state
}

\author{
Listeria monocytogenes em presuntos fatiados \\ em supermercados da cidade de Recife, Pernambuco
}

\author{
Jéssica Martins de Andrade ${ }^{*}$ (1), Fernanda Maria de Lino Moura' (D), \\ Thayná Milena Siqueira Souza Silva' ${ }^{1}$, Elizabeth Sampaio de Medeiros ${ }^{1}$
}

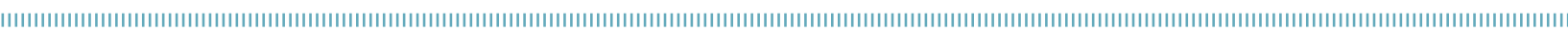

\begin{abstract}
The aim of this study was to investigate Listeria monocytogenes in ham sliced in supermarkets in Recife city, Pernambuco state. In total, 40 samples of sliced ham were collected, and $25 \mathrm{~g}$ of ham was added to $225 \mathrm{~mL}$ of Demi Fraser broth. After incubation, $0.1 \mathrm{~mL}$ was inoculated in Fraser broth and, subsequently, sown in supplemented Listeria Selective Agar, based on Otaviani and Agosti. The following tests were carried out for confirmation purposes: Gram stain, motility test, catalase test and cAMP test. There was L. monocytogenes in $25 \%$ (10/40) of the samples. The presence of $L$. monocytogenes in ready-toeat food, such as sliced ham, is likely related to lack of proper equipment-cleaning in supermarkets, a fact that poses great risk to public health.
\end{abstract}

KEYWORDS: ready-to-eat food; sausages; pathogenic microorganisms; public health.
RESUMO: Objetivou-se com esse estudo realizar a pesquisa de Listeria monocytogenes em presuntos fatiados em supermercados da cidade de Recife, Pernambuco. Foram adquiridas 40 amostras de presuntos fatiados. Para o isolamento, foram utilizados $25 \mathrm{~g}$ do alimento para $225 \mathrm{~mL}$ do caldo Demi Fraser, após incubaçáo, inoculou-se $0,1 \mathrm{~mL}$ em caldo Fraser e posteriormente realizou-se a semeadura em Agar seletivo suplementado para Listeria de acordo com Otaviani e Agosti. Como testes confirmatórios, foram realizados a coloração de Gram, teste de motilidade, teste da catalase e teste de cAMP. Identificou-se a presença de $L$. monocytogenes em 25\% (10/40) das amostras. A presença da L. monocytogenes em alimentos prontos para consumo, como o presunto fatiado, é de grande risco à saúde pública e pode estar relacionada à ocorrência de falhas na higienizaçáo dos equipamentos nos supermercados.

PALAVRAS-CHAVE: alimentos prontos para consumo; embutidos; micro-organismos patogênicos; saúde pública. 
The increased demand for industrialized, chilled and ready-toeat food has been contributing to increase the risk of outspreading food-transmitted diseases (FAI et al., 2011). The pathogen Listeria monocytogenes is the cause of listeriosis cases, and it stands out among agents responsible for such contaminations. Although this disease has low incidence, it accounts for high mortality rates (LIU et al., 2015; LUO et al., 2017); its manifestation can be invasive such as meningitis, septicemia and miscarriage, as well as non-invasive, like gastroenteritis followed by fever and vomiting (IACUMIN et al., 2016). Pregnant women, newborn babies, immunocompromised patients and elderlies are the individuals most susceptible to the invasive forms of listeriosis (OXARAN et al., 2017; WIECZOREK; OSEK, 2017).

The ubiquitous microorganism Listeria monocytogenes is found in different environments such as soil, water, animals and humans, a fact that hinders its elimination from foodprocessing environments (FIGUEIREDO, 2015; IACUMIN et al., 2016; LEONG et al., 2017). The demand for readyto-eat meat food is high, since it became a significant part of contemporary diet, but such demand increases the possibility of contamination by L. monocytogenes throughout postprocessing stages (WANG et al., 2016).

Thus, it is essential to prevent cross contamination in processing facilities, mainly the contamination of chilled products, since this pathogen is a psychotropic microorganism. This storage system does not demand any other post-processing stage to inactivate this microorganism (IACUMIN et al., 2016; LEONG et al., 2017); therefore, the aim of this study is to assess the presence of Listeria monocytogenes in ham sliced in supermarkets in Recife city, Pernambuco State.

Forty (40) samples of sliced ham were collected in supermarkets in Recife city, Pernambuco state. The selected chain of supermarkets has implemented good manufacturing practices. The samples were collected from packages within the expiration date, which was printed on package labels by employees in charge of handling and packing food. The samples were packed, placed in coolers filled with recycling ice and taken to the laboratory where the analyses were carried out.

Method ISO 11290-1:1996/Amd.1:2004, with adaptations, was adopted as isolation procedure. The aliquot of $25 \mathrm{~g}$ of ham samples was added to $225 \mathrm{~mL}$ of Demi Fraser $\left(\right.$ Acumedia $^{\circledR}$ ) preheating broth supplemented with $1 \mathrm{~g}$ of Ammonium Citrate and Purest Iron III $\left(\mathrm{Vetec}^{\circledR}\right)$ and incubated in bacteriological incubator for 24 hours at $30^{\circ} \mathrm{C}$. After the end of this process, $0.1 \mathrm{~mL}$ of it was inoculated with $10 \mathrm{~mL}$ of enriched Fraser broth $\left(\right.$ Merck $^{\circledR}$ ) supplemented with $0.5 \mathrm{mg}$ of Ammonium Citrate and Purest Iron III $\left(\right.$ Vetec $\left.^{\circledR}\right)$ - this mixture was incubated for 48 hours at $37^{\circ} \mathrm{C}$. Next, sowing was carried out through depletion in Petri dishes filled with Listeria Selective Agar ChromoCult ALOA $\left(\right.$ Merck $\left.^{\circledast}\right)$ supplemented with $5 \mathrm{mg}$ of Amphotericin B (Cristália Laboratory) and $10 \mathrm{mg}$ of Ceftazidime (Antibióticos do Brasil - ABL), based on Ottaviani and Agosti. The samples were, then, incubated at $37^{\circ} \mathrm{C}$ for 24 to 48 hours for further observation about the presence, or not, of blueish colonies, which feature $L$. monocytogenes.

Colonies indicative of $L$. monocytogenes were subjected to confirmation tests, namely: Gram stain, motility test, catalase test and cAMP test. Gram stain was conducted based on BARROW; FELTHAM (1993) to assess the presence of Gram-positive bacilli characteristic of genus Listeria. Motility test was carried out in tubes filled with $3 \mathrm{~mL}$ of SIM medium $\left(\right.$ Himedia $^{\circledR}$ ) inoculated with up to $2 / 3$ of an isolated colony of this microorganism. Samples were incubated at room temperature for 3 to 5 days. Tubes where the medium became bleared and umbrella-shaped were considered positive for L. monocytogenes (BARROW; FELTHAM, 1993). A colony previously sown in Petri dishes filled with Chromocult Agar Selective Listeria - Aloa, $\left(\right.$ Merck $\left.^{\circledR}\right)$ and placed on glass slides, based on Ottaviani and Agosti, was used in the catalase test. A drop of $3 \%$ hydrogen peroxide was added to the sample in order to observe the formation of air bubbles characteristic of genus Listeria (BARROW; FELTHAM, 1993).

$\beta$-hemolysis was tested in Petri dishes filled with 5\% mutton blood agar. After inoculation through stinging, the dishes were incubated at $37^{\circ} \mathrm{C}$ for 24 hours and evaluated for the presence of zones of hemolysis caused by $\beta$-hemolysin production (BARROW; FELTHAM, 1993).

The cAMP test was conducted in Petri dishes filled with $5 \%$ mutton blood agar, which was initially inoculated at vertical line with a $\beta$-hemolysis Staphylococcus aureus sample. Subsequently, the sample to be tested was inoculated in position perpendicular to the inoculation line of $S$. aureus, but without touching it. The dishes were incubated at $35^{\circ} \mathrm{C}$ for 24 hours. The sample was considered positive for $L$. monocytogenes when it produced an extracellular protein (factor cAMP), which enlarges the zone of hemolysis produced by $S$. aureus (BARROW; FELTHAM, 1993).

The strain of L. monocytogenes from the American Type Culture Collection used as positive control was provided by the Ministry of Agriculture, Livestock and Supply (ATCC ${ }^{\circledR}$ $19115^{\mathrm{TM}}$ ). It was stored in agar and renewed on a monthly basis.

Ten (10) of the 40 samples collected in supermarkets in Recife city, Pernambuco State, were positive for contamination by L. monocytogenes; therefore, $25 \%$ (10/40) of the samples were positive. The amount of samples positive for contamination by $L$. monocytogenes was relevant if one takes into account the public health context, since the ham samples were collected in a chain of supermarkets that have implemented good manufacturing practices and the presence of this microorganism suggests flaws in them.

Similar studies corroborate the present results, FAI et al. (2011) found that $42.5 \%$ of supermarkets in Fortaleza city, Ceará State, presented ham samples contaminated by $L$. monocytogenes and MENA et al. (2004) observed this microorganism in $25 \%$ of ham samples collected in supermarkets 
in Portugal. VITAS et al. (2004) assessed the presence of L. monocytogenes in pork meat products handled in supermarkets in Narrava city, Spain - the bacterium was detected in $18.2 \%$ of the collected samples. PETTINATI et al. (2006) investigated the presence of this microorganism in hot-dog sausage samples collected in supermarkets in São Paulo city; $14 \%$ of their samples were positive for contamination by it.

Data collected by LAPENDA (2010) pointed towards the presence of L. monocytogenes in $12.5 \%$ of ham samples collected in supermarkets in Recife city; therefore, their results presented lower values than the ones in the current study.

ANGELIDIS; KOUTSOUMANIS (2006) observed contamination by $L$. monocytogenes in $8.1 \%$ of sliced ham samples collected in a chain of supermarkets in Greece. Similar results were recorded by PÉREZ-RODRIGUEZ et al. (2010), who reported contamination in $7.25 \%$ of sliced ham and bacon samples collected in mid- and big-sized supermarkets in Cordoba city, Spain.

MARTINS (2009) carried out a research in Sáo Paulo city, São Paulo state, and FIGUEIREDO (2015) did the same in Salvador city, Bahia state. Their results did not meet the present ones, because their numbers were much lower than those in the current study -0.8 and $2.2 \%$, respectively, for the presence of this microorganism in sliced ham samples collected in local supermarkets.

The herein recorded values highlight the need of closer attention by bureaus in charge of public health issues. They must set standards for the presence of this microorganism in meat products, mainly in ready-to-eat food. If one takes into consideration that $L$. monocytogenes presents low infective dose, contamination by it is easier if there are no post-processing stages to eliminate its presence before food consumption (OLIVEIRA et al., 2010). However, the Brazilian legislation still lacks official patterns for the presence and outspread of L. monocytogenes in raw meat and meat products. Such factor impairs the quality inspection of these products in retail shops.

Ham is subjected to thermal treatment to eliminate $L$. monocytogenes and it suggests that its contamination happens during post-processing stages; therefore, it results from cross contamination at product handling. The slicing process increases the risk of contamination due to hygiene conditions adopted throughout ham handling and to its contact with inappropriately cleaned surfaces (FAI et al., 2011). Thus, it is essential providing proper training to employees in charge of handling these products in order to reduce contamination by L. monocytogenes. They must be informed about the need of properly performing the sanitation process, as well as about how to apply good manufacturing practices in an adequate way (PÉREZ-RODRÍGUEZ et al., 2010).

Listeria monocytogenes identification in ready-to-eat food, such as in sliced ham, can be related to cross contamination and to equipment sanitation flaws in supermarkets, a fact that poses great risk to public health. Thus, it is essential to train food handlers on how to apply good manufacturing practices in processing environments, as well as having constant monitoring, either by inspection bureaus in charge of it or by the ones in charge of such inspection in retailers. These practices ensure that consumers will acquire contamination-free food.

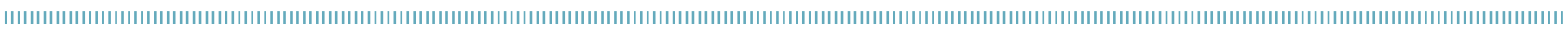
REFERENCES

ANGELIDIS A.S.; KOUTSOUMANIS, K. Prevalence and concentration of Listeria monocytogenes in sliced readyto-eat meat products in the hellenic retail Market. Journal of Food Protection, Estados Unidos, v.69, n.4, p.938-942, 2006. Available from: <http://jfoodprotection.org/doi/ pdf/10.43 15/0362-028X-69.4.938?code=fopr-site $>$. Access on: Jan. 122018.

BARROW. G.I.; FELTHAM. R.K.A. Manual for the Identification of Medical Bacteria. 3. ed. Cambridge: Cambridge University Press, 1993.

FAI, E.A.C.; FIGUEIREDO, E.A.T.; VERDIN, S.E.F.; PINHEIRO, N.M.S.; BRAGA, A.R.C.; STAMFORD, T.L.M. Salmonella sp. and Listeria monocytogenes in fully cooked ham commercialized in supermarkets of Fortaleza (CE, BRASIL): risk factor for public health. Ciência \& Saúde Coletiva, Rio de Janeiro, v.16, n.2, p.657-662, 2011 . Available from: <http://www.scielo.br/scielo. php?script=sci_arttext\&pid=S1413-81232011000200029>. Access on: Dec. 16 2017. http://dx.doi.org/10.1590/ S1413-81232011000200029
FIGUEIREDO, A.C.L. Listeria monocytogenes em produtos cárneos fatiados prontos para consumo e ação de antimicrobianos no controle da contaminação. 2015. 77f. Dissertation (Master's degree in Food Science) - Universidade Federal da Bahia, Salvador, 2015. Available from: < http://www.pgalimentos.far.ufba.br/ sites/pgalimentos.far.ufba.br/files/dissertacao_ana_claudia_ figueiredo.pdf>. Access on: Jan. 282018.

IACUMIN, L.; MANZANO, M.; GIUSEPPE COMI, G. Phage Inactivation of Listeria monocytogenes on San Daniele Dry-Cured Ham and Elimination of Biofilms from Equipment and Working Environments. Microorganisms, v.4, n. 1, p.1-12, 2016. Available from: <https:// www.mdpi.com/2076-2607/4/1/4>. Access on: Mar. 292018. https://doi.org/10.3390/microorganisms4010004

INTERNATIONAL ORGANIZATION FOR STANDARDIZATION (ISO). ISO 1 1290-1:1996/Amd. 1:2004 Microbiological of food and animal feeding stuffs - Horizontal method for the detection and enumeration of Listeria monocytogenes - part 1: detection method. AMENDMENT 1: Modification of the isolation media and the haemolysis test, and inclusion of precision data. Geneve: ISO, 2004. 4p. 
LAPENDA, A.M.V.S. Ocorrência de Listeria spp. em embutidos resfriados comercializados na cidade do Recife-PE. 2010. $86 \mathrm{f}$. Dissertation (Master's degree in Food Science and Techonology) - Universidade Federal Rural de Pernambuco, Recife, 2010. Available from: <http://www.tede2.ufrpe.br:8080/tede/handle/ tede2/5071 >. Access on: Jan. 142018.

MARTINS, E.A. Listeria monocytogenes em produtos fatiados do tipo read-to-eat, presunto cozido e salame, comercializados no município de São Paulo: Ocorrência, quantificação e sorotipagem. 2009. $76 \mathrm{f}$. Thesis (Doctor's degree in Public Health Practice) - Universidade de São Paulo, São Paulo, 2009. Available from: <http://www.teses.usp.br/teses/ disponiveis/6/6135/tde-06042011-151104/pt-br.php>. Access on: Mar. 162018.

MENA, C.; ALMEIDA, G.; CARNEIRO, L.; TEIXEIRA, P.; HOGG, T.; GIBBS, P.A. Incidence of Listeria monocytogenes in different food products commercialized in Portugal. Food Microbiology, Inglaterra, v.21, n.2, p.213-216, 2004. Available from: <https://www. sciencedirect.com/science/article/pii/S0740002003000571>. Access on: Mar. 25 2018. https://doi.org/10.1016/ S0740-0020(03)00057-1

LEONG, D.; NICAOGÁIN, K.; LUQUE-SASTRE, L.; MCMANAMON, O.; HUNT, K.; ALVAREZ-ORDÓÑEZ, A.; SCOLLARD, J.; SCHMALENBERGER, A.; FANNING, S.; O'BYRNE, C.; JORDAN, K. A 3-year multi-food study of the presence and persistence of Listeria monocytogenes in 54 small food businesses in Ireland. International Journal of Food Microbiology, Low Countries, v.249, p. 18-26, 2017. Available from: <https://www.ncbi.nlm.nih.gov/ pubmed/2827 1853>. Access on: Jan. 04 2018. https://doi. org/10.1016/j.ijfoodmicro.2017.02.015

LIU, H.; LU, L.; PAN, Y.; SUN, X.; HWANG, C. ZHAO, Y.; WU, V. Rapid detection and differentiation of Listeria monocytogenes and Listeria species in deli meats by a new multiplex PCR method. Food Control, v.52, p.78-84, 2015. Available from: $<$ https://www.deepdyve.com/lp/elsevier/rapid-detection-anddifferentiation-of-listeria-monocytogenes-and-UgVAqUgKTf $>$. Access on: Jan. 292018.

LUO, L.; ZHANG, Z.; WANG, H.; WANG, P.; LAN, R.; DENG, J.; MIAO, Y; WANG, Y. WANG, Y.; XU, J.; ZHANG, L.; SUN, S.; LIU, X.; ZHOU, Y.; CHEN, X.; LI, Q., YE, C. A 12-month longitudinal study of Listeria monocytogenes contamination and persistence in pork retail markets in China. Food Control, v.76, p.66-73, 2017. Available from: <https://www.sciencedirect.com/science/article/pii/ S0956713516307277\#! >. Access on: 12.fev.2018.
OLIVEIRA, M.M.M.; BRUGNERA, D.F.; PICCOLI, R.H. Biofilmes microbianos na indústria de alimentos: uma revisão. Revista do Instituto Adolfo Lutz, v.69, n.3, p.277-284, 2010. Available from: <http://www.ial.sp.gov.br/resources/insituto-adolfo-lutz/publicacoes/ rial/10/rial69_3_completa/1289.pdf>. Access on:21.mar.2018.

OXARAN, V.; LEE, S.H.I.; CHAUL, L.T.; CORASSIN, C.H.; BARANCELLI, G.V.; ALVES, V.F.; DE OLIVEIRA, C.A.F.; GRAM, L.; DE MARTINIS, E.C.P. Listeria monocytogenes incidence changes and diversity in some Brazilian dairy industries and retail products. Food Microbiology, England, v.68, p.16-23, 2017. Available from: <https://www.ncbi.nlm.nih.gov/pubmed/28800821 >. Access on: Mar. 21 2018. https://doi.org/10.1016/j.fm.2017.06.012

PÉREZ-RODRÍGUEZ, F.; CASTRO.R.; POSADA-IZQUIERDO, G.D.; VALERO, A.; CARRASCO, E.; GARCÍA-GIMENOG, R.M.; ZURERA, G. Evaluation of hygiene practices and microbiological quality of cooked meat products during slicing and handling at retail. Meat Science, England, v.86, n.2, p.479-485, 2010. Available from: <https://www.sciencedirect.com/ science/article/pii/SO309174010002238>. Access on: Jan. 30 2018. https://doi.org/10.1016/j.meatsci.2010.05.038

PETTINATI, N.N.; TELLES, E.O.; BALIAN, S.C. Listeria monocytogenes in hot dog sausages obtained from groceries stores in the city of São Paulo - a comparative and retrospective analysis of human listeriosis isolates. Veterinária e Zootecnia, v.13, n.2, p.182-191, 2006. Available from: <http://www.fmvz.unesp.br/revista/volumes/ vol13_n2/VZ13_2(2006)_182-191.pdf>.Access on: Feb. 022018.

VITAS, A.I.; AGUADO, V.; GARCIA-JALON, I. Occurrence of Listeria monocytogenes in fresh and processed foods in Navarra (Spain). International Journal of Food Microbiology, v. 90, p. 349- 356, 2004. Available from: <https://www.sciencedirect.com/science/article/abs/ pii/SO168160503003143?via\%3Dihub> Access on: 09.fev.2018.

WANG, X.; UYTTENDAELE, M.; GEERAERD, A.; STEEN, L.; FRAEYE, I.; DEVLIEGHERE, F. Thermal inactivation kinetics of surface contaminating Listeria monocytogenes on vacuum-packaged agar surface and ready-to-eat sliced ham and sausage. Food Research International, Canada, v.89, Pt. 1, p.843-849, 2016. Available from: <https://www.ncbi.nlm.nih.gov/pubmed/28460987>. Access on: Feb. 14 2018. https://doi.org/10.1016/j.foodres.2016.10.019

WIECZOREK, K.; JACEK OSEK, J. Prevalence, genetic diversity and antimicrobial resistance of Listeria monocytogenes isolated from fresh and smoked fish in Poland. Food Microbiology, England, v.64, p. 164-171, 2017. Available from: <https://www.sciencedirect. com/science/article/pii/S0740002016306827>. Access on: Feb. 02 2018. https://doi.org/10.1016/j.fm.2016.12.022 